\title{
Resting and re-emergent tongue tremor in Parkinson's disease
}

\author{
Ayaka Numao, Keisuke Suzuki, Hiroaki Fujita, Koichi Hirata
}

\begin{abstract}
- Additional material is published online only. To view please visit the journal online (http://dx.doi.org/10.1136/ bcr-2017-221808).
\end{abstract}

Department of Neurology, Dokkyo Medical University, Tochigi, Japan

\section{Correspondence to Dr Keisuke Suzuki, keisuke@dokkyomed.ac.jp}

Accepted 19 October 2017

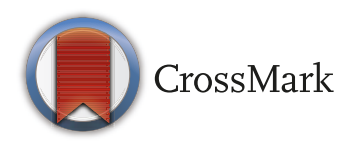

To cite: Numao A, Suzuki K, Fujita $\mathrm{H}$, et al. BMJ Case Rep Published Online First: [please include Day Month Year]. doi:10.1136/bcr-2017221808

\section{DESCRIPTION}

An 82-year-old man was referred to our department for re-evaluation of parkinsonism. The patient had a 2-year history of parkinsonism followed by dementia and was treated with $300 \mathrm{mg}$ of levodopa/decarboxylase inhibitor. The patient previously had a significant response of motor symptoms including rest and re-emergent tremor to levodopa therapy. The medical history included chronic subdural haematoma. Neurological examination showed bradykinesia and rigidity involving the neck and upper and lower extremities. Resting tremor at the jaw, tongue and right foot was observed. Re-emergent tongue tremor was observed (see online supplementary video). The patient was in Hoehn and Yahr stage 5 in an 'on' state. He had dementia with visual hallucinations. Brain MRI showed diffuse cortical atrophy with preserved midbrain tegmentum and pons. A diagnosis of Parkinson's disease (PD) with dementia was made. Reduced uptake of the early and delayed heart-to-mediastinum ratios of cardiac 123I-metaiodobenzylguanidine scintigraphy and anosmia supported the diagnosis.

Resting tremor is the characteristic motor sign in $\mathrm{PD}$, predominantly affecting the unilateral upper extremity, but it can be seen in the other body regions including the lips, jaw and tongue with a uniform frequency of 4 to $6 \mathrm{~Hz} .{ }^{1} \mathrm{PD}$-related postural tremor, 're-emergent tremor', is different from essential tremor in the delayed appearance and a similar frequency to rest tremor. Re-emergent tremor is usually observed in the hand of the patient, but can affect the other body parts. ${ }^{2}$ The re-emergent tongue tremor as the first manifestation of PD has been

\section{Learning points}

- We report on a patient with Parkinson's disease (PD) showing the re-emergent feature of the tongue tremor.

- Re-emergent tremor is usually observed in the hand of the PD patient, but can affect the other body parts such as the tongue.

rarely described. ${ }^{3}$ We here report resting and re-emergent nature of the tongue tremor in PD.

Contributors AN has contributed to the design of the study, the diagnosis and treatment of the patient and interpretation of data and has written the first draft of the manuscript. KS has contributed to the design of the study, the diagnosis and treatment of the patient, interpretation of data and has written the manuscript. HF has contributed to the design of the study and interpretation of data. KH has contributed to the design of the study and revising the manuscript. All authors gave final approval of the final version to be submitted.

Competing interests None declared.

\section{Patient consent Obtained.}

Provenance and peer review Not commissioned; externally peer reviewed.

(C) BMJ Publishing Group Ltd (unless otherwise stated in the text of the article) 2017. All rights reserved. No commercial use is permitted unless otherwise expressly granted.

\section{REFERENCES}

1 Hunker CJ, Abbs JH. Uniform frequency of parkinsonian resting tremor in the lips, jaw, tongue, and index finger. Mov Disord 1990;5:71-7.

2 Jankovic J. Parkinson's disease: clinical features and diagnosis. J Neurol Neurosurg Psychiatry 2008;79:368-76.

3 Delil Ş, Bölükbașı F, Yeni N, et al. Re-emergent Tongue Tremor as the Presenting Symptom of Parkinson's Disease. Balkan Med J 2015;32:127-8.

Copyright 2017 BMJ Publishing Group. All rights reserved. For permission to reuse any of this content visit http://group.bmj.com/group/rights-licensing/permissions.

BMJ Case Report Fellows may re-use this article for personal use and teaching without any further permission.

Become a Fellow of BMJ Case Reports today and you can:

- Submit as many cases as you like

- Enjoy fast sympathetic peer review and rapid publication of accepted articles

- Access all the published articles

- Re-use any of the published material for personal use and teaching without further permission

For information on Institutional Fellowships contact consortiasales@bmjgroup.com

Visit casereports.bmj.com for more articles like this and to become a Fellow 